Jurnal Pendidikan Ekonomi: Jurnal Ilmiah Ilmu Pendidikan, Ilmu Ekonomi, dan Ilmu Sosial \begin{tabular}{l|l|l} 
ISSN 1907-9990 & E-ISSN 2548-7175 & Volume 11 Nomor 1 (2017)
\end{tabular}

\title{
STRATEGI BAURAN PEMASARAN KERAJINAN TENUN IKAT PADA CV. SILVI MN PARADILA DI DESA PARENGAN KECAMATAN MADURAN KABUPATEN LAMONGAN
}

\author{
Nasehatul Khoiriyah ${ }^{1}$, Joko Widodo ${ }^{1}$, Hety Mustika Ani ${ }^{1}$ \\ ${ }^{1}$ Program Studi Pendidikan Ekonomi, Fakultas Keguruan dan Ilmu Pendidikan, Universitas Jember
}

\begin{abstract}
The marketing mix strategy is one of the efforts undertaken by the company to increase product sales and earn profits for the company consisting of four groups, namely: product, price, promotion, and place or distribution channel. This study aims to describe the marketing mix strategy related to product, price, promotion, and place conducted by the owner of tenun ikat handicraft business of CV. Silvi MN Paradila in Parengan village, Maduran district, Lamongan regency. This research is a descriptive qualitative research. Determination of research location uses purposive area method, while the determination of subject and informant research using purposive method. Data collection uses observation methods, interviews, and documents. Data analysis used in this research is data reduction, data presentation, and drawing conclusion. The result of the research shows that marketing mix strategy related to product, price, promotion, and place conducted by the owner of tenun ikat handicraft business, namely: product strategy by maintaining product quality, and providing various motives. Pricing strategies are by setting the selling price of the cost of goods and profit margins and setting prices based on 3 levels: low, medium, and high. Promotional strategies are with advertising, publicity, personal selling, and direct marketing. As for the distribution is using direct and indirect distribution.
\end{abstract}

Keywords: The Marketing Mix Strategy, Product, Price, Promotion, Place

\section{PENDAHULUAN}

Industrialisasi merupakan suatu proses interaksi antara pengembangan teknologi, inovasi, dan perdagangan antarnegara. Sektor industrialisasi diyakini sebagai sektor yang dapat memajukan perekonomian. Adanya pandangan bahwa industrialisasi merupakan langkah awal pembangunan ekonomi negara berkembang menyebabkan Indonesia ikut mengembangkan industri, baik sektor industri besar maupun sektor industri kecil, baik di perkotaan ataupun di pedesaan. Sektor industri kecil memiliki peranan yang besar dalam mendorong pembangunan daerah, khususnya pembangunan di pedesaan. Sektor industri kecil merupakan usaha yang kini menjadi perhatian karena merupakan komponen utama untuk mengembangkan pembangunan daerah.

Salah satu sektor industri kecil yang mampu mengembangkan pembangunan daerah yaitu kerajinan tenun. Kerajinan tenun merupakan salah satu keanekaragaman warisan budaya Indonesia yang harus dilestarikan. Hal ini dapat dilihat dari segi warna, ragam hias, dan jenis bahan serta benang yang digunakan. Sehingga di Indonesia kini memiliki bermacam-macam motif dan jenis tenun, seperti di Jepara terdapat tenun troso, di Banten terkenal dengan tenun badui dan juga di Jawa Timur terdapat tenun ikat. Slah satunya tenun ikat yang ada di Jawa Timur terletak di Kabupaten Lamongan.

Seperti di Jepara terdapat tenun troso, di Banten terkenal dengan tenun badui dan juga di Jawa Timur terdapat tenun ikat. Salah satu tenun ikat yang ada di Jawa Timur terletak di Kabupaten Lamongan. Pengusaha kerajinan tenun ikat selain memproduksi tenun ikat juga harus memperhatikan bagaimana menarik para konsumen agar membeli produk yang dihasilkan, maka pengusaha kerajinan tenun ikat harus memiliki strategi pemasaran, strategi pemasaran ada berbagai macam salah satunya yaitu strategi bauran pemasaran. Menurut 
Radiany dan Sularso (2007: 43) bauran pemasaran (Marketing Mix) merupakan kombinasi dari sifat-sifat produk, harga, promosi, dan tempat atau lokasi yang digabungkan untuk dijadikan penawaran khusus.

Berdasarkan empat elemen yang terkait dengan strategi bauran pemasaran tersebut, produk merupakan titik pusat dari kegiatan pemasaran karena produk merupakan hasil dari perusahaan yang dapat ditawarkan ke pasar untuk konsumen. Menurut Kotler dan Amstrong (2008: 266) produk sebagai segala sesuatu yang dapat ditawarkan kepada pasar agar menarik perhatian, akuisisi, penggunaan, atau konsumsi yang dapat memmuaskan suatu keinginan atau kebutuhan. Produk merupakan bauran pemasaran yang paling mendasar. Produk tidak hanya objek fisik, tetapi merupakan seperangkat manfaat atau nilai yang dapat memuaskan kebutuhan pelanggan. Menurut Subagyo (2010: 321) beberapa keunggulan yang dapat dilihat dari elemenelemen produk supaya produk yang dipasarkan laku: a. Kualitas produk; b. Ciri khas produk; c. Desain produk; d. Gaya produk; e. Kemasan produk; f. Pelayanan.

Harga sebagai salah satu variabel bauran pemasaran selain produk, tempat, dan promosi. Harga juga mempunyai peranan yang sangat penting bagi perusahaan untuk menjangkau pasar sasaran atau untuk menarik pembeli. Penetapan suatu harga tergantung pada kebijakan perusahaan tetapi tentu saja dengan mempertimbangkan berbagai hal. Harga dapat dikatakan mahal, murah, atau sedang tergantung dari lingkungan kehidupan dan kondisi individu atau konsumen, agar dapat sukses dalam memasarkan suatu barang setiap perusahaan harus menetapkan harganya secara tepat, karena harga merupakan satu-satunya unsur marketing mix yang menentukan keuntungan dan kelangsungan hidup perusahaan.

Promosi ditunjukkan untuk mempengaruhi konsumen agar mengenal produk yang ditawarkan oleh perusahaan dan konsumen agar tertarik dalam membeli produk tersebut. Menurut Tjiptono, dkk (2008: 517) Ada lima macam saran promosi yang dapat digunakan oleh setiap perusahaan dalam mempromosikan produknya: a. Periklanan (Advertising); b. Penjualan perorangan (Personal selling); c. Publisitas (Public relation); d. Promosi penjualan (Sales promotion); e. Pemasaran langsung (Direct marketing).

Tempat merupakan kegiatan perusahaan yang membuat produk tersedia bagi pelanggan sasaran meliputi; lokasi, saluran distribusi, persediaan dan transportasi. Menurut Kotler dan Armstrong (dalam Nugroho dan Japarianto, 2001:55) place adalah: "Place includes company activities that make product available to target consumers." Tempat termasuk kegiatan-kegiatan perusahaan yang membuat produk tersedia bagi pelanggan sasaran. Menyalurkan produk tersebut secara cepat dan tepat tentu saja haruslah diketahui dimana tempat konsumen berada, tanpa mengetahui lokasi atau tempat tinggal konsumen maka penyaluran barang-barang itu akan menjadi tidak efektif dan tidak efisien, untuk keperluan tersebut pengusaha dapat menggunakan berbagai bentuk saluran distribusi, saluran distribusi yang dapat dilakukan baik distribusi secara langsung maupun saluran distribusi secara tidak langsung.

Berdasarkan penjelasan diatas, maka peneliti tertarik untuk melakukan penelitian dengan judul "Strategi Bauran Pemasaran kerajinan tenun ikat pada CV. Silvi MN Paradila di Desa Parengan Kecamatan Maduran Kabupaten Lamongan”. 


\section{METODE PENELITIAN}

Jenis penelitian ini merupakan penelitian deskriptif yang menggunakan pendekatan kualitatif. Peneliti menggunakan deskriptif kualitatif sebab peneliti ingin menggambarkan strategi bauran pemasaran kerajinan tenun ikat pada CV. Silvi MN Paradila di Desa Parengan Kecamatan Maduran Kabupaten Lamongan. Penentuan lokasi penelitian menggunakan metode Purposive Area dengan menentukan Desa Parengan Kecamatan Maduran Kabupaten Lamongan sebagai lokasi penelitian, sedangkan untuk penentuan subjek dan informan penelitian menggunakan metode Purposive, dimana informan utama dalam penelitian ini adalah pemilik usaha kerajinan tenun ikat CV. Silvi MN Paradila dan informan pendukung dalam penelitian ini adalah konsumen produk tenun ikat CV. Silvi MN Paradila. Jenis dan sumber data yang digunakan adalah data primer dan data sekunder. Metode pengumpulan data menggunakan metode wawancara, observasi, dan dokumen. Dan metode analisis data yang digunakan adalah kegiatan reduksi data, penyajian data, dan penarikan kesimpulan.

\section{HASIL DAN PEMBAHASAN}

\section{Hasil Penelitian}

Bauran pemasaran merupakan suatu cara yang dilakukan oleh para pengrajin dalam menjalankan usaha agar produknya bisa diminati oleh konsumen dan untuk mendapatkan suatu keuntungan tersendiri bagi perusahaan tersebut, dalam menjalankan suatu usaha sangatlah diperlukan strategi bauran pemasaran yang didalamnya meliputi empat unsur bauran pemasaran yaitu: produk, harga, promosi dan tempat.

\section{Produk}

a. Kualitas produk: Pemilik usaha kerajinan tenun ikat CV. Silvi MN Paradila di Desa Parengan Kecamatan Maduran Kabupaten Lamongan untuk menjaga kualitas produk, bisa dilihat dari bahan-bahan yang digunakan dalam pembuatan kain tenun ikat, bahan diproses sedemikian rupa sehingga menjadi suatu kain tenun ikat yang berkualitas. Bahan utama yang dibutuhkan dalam pembuatan tenun ikat adalah benang. Adapun benang yang digunakan dalam pembuatan kain tenun ikat Lamongan ini, ada tiga jenis benang yang digunakan yaitu, benang stafel fiber, benang katun mercerised (mercerized cotton), dan benang sutera.

b. Ciri khas produk: Ciri khas dari produk tenun ikat Desa Parengan Lamongan ini yaitu ikan bandeng dan lele, karena ikan bandeng dan lele merupakan icon Kabupaten Lamongan. Hal tersebut sesuai yang diungkapkan pemilik usaha kerajinan tenun ikat, yang mengatakan:

"Ciri khas dari produk tenun ikat ini yaitu milik daerah sendiri mbak ikan

bandeng dan lele, karena ikan bandeng dan lele merupakan icon Kabupaten

Lamongan mbak, sehingga kami mneggunakan motif produk ikan bandeng dan lele sebagai ciri khas produk kami mbak" (MK, 55 $\left.{ }^{\text {th }}\right)$.

c. Kemasan produk: Kemasan produk digunakan untuk membungkus produk-produk yang telah jadi, agar kain tenun ikat terlihat rapi, terhindar dari gesekan benda lain. Pemilik usaha kerajinan tenun ikat menyediakan 2 kemasan untuk produk kerajinan tenun ikat ini yaitu, kemasan plastik dan kotak. Plastik digunakan untuk mengemas kain tenun ikat, sedangkan kemasan kotak digunakan untuk mengemas sarung tenun ikat. 


\section{Harga}

Pemilik usaha kerajinan tenun ikat di Desa Parengan Kecamatan Maduran Kabupaten Lamongan menetapkan harga produk tenun ikat berdasarkan total biaya keseluruhan + profit margin yang ditentukan serta permintaan konsumen.

a. Penetapan harga berdasarkan biaya: Penetapkan harga yang ditetapkan pemilik usaha kerajinan tenun ikat melihat besarnya harga dari total biaya keseluruhan dan laba yang ditentukan, total biaya keseluruhan seperti: biaya produksi, biaya tenaga kerja produksi, dan biaya pemasaran. Biaya produksi meliputi; biaya bahan baku dan biaya bahan tambahan, untuk biaya pemasaran meliputi; biaya promosi, biaya pengiriman. Hal tersebut sesuai yang diungkapkan pemilik usaha kerajinan tenun ikat Bapak Miftahul Khoiri, beliau mengatakan:

"Untuk penetapan harga kami tentukan dari total seluruh biaya mbak, seperti biaya poduksi, biaya tenaga kerja produksi, biaya pemasaran yang dikeluarkan dan laba yang sudah kami tentukan mbak, dengan cara 90\% untuk keseluruhan total biaya dan 10\% untuk laba mbak" (MK, 55 $\left.5^{\text {th }}\right)$.

Dari penetapan harga berdasarkan biaya maka pemilik usaha kerajinan tenun ikat dapat menentukan harga menjadi beberapa tingkatan harga, yaitu; rendah, sedang, dan tinggi.

b. Penetapan harga berdasarkan permintaan konsumen: Pemilik usaha kerajinan tenun ikat juga menetapkan harganya berdasarkan permintaan konsumen, dengan adanya penetapan harga ini maka konsumen dapat memesan tenun ikat sesuai dengan kebutuhan dan keinginannya. Pemilik usaha kerajinan tenun ikat ini pernah menerima pesanan dari pemerintah daerah Kabupaten Lamongan. Selain itu, ada konsumen yang memesan tenun ikat sebagai cinderamata, dan untuk acara resmi.

\section{Promosi}

Kegiatan promosi yang dilakukan oleh pemilik usaha kerajinan tenun ikat di Desa Parengan Kecamatan Maduran Kabupaten Lamongan yaitu, untuk memperkenalkan produk yang dihasilkan kepada konsumen, ada beberapa promosi yang dilakukan oleh pemilik usaha kerajina tenun ikat diantaranya promosi melalui pengiklanan (Advertising), penjualan perorangan (Personal selling), publisitas, dan pemasaran langsung (Direct Marketing).

a. Periklanan: Promosi yang dilakukan dengan pengiklanan yaitu melalui media cetak dan media elektronik seperti koran, televisi, dan kartu nama

b. Penjualan perorangan: Pemilik usaha kerajinan tenun ikat juga melakukan promosinya melalui penjualan perorangan (personal selling), pemilik usaha kerajinan tenun ikat melakukan promosi tersebut sudah sejak lama promosi tersebut dilakukan dengan mendirikan toko sendiri yang terletak di Desa Parengan.

c. Publisitas: Selain menggunakan promosi pengiklanan pemilik usaha kerajinan tenun ikat juga mempromosikan produk tenun ikat dengan cara publisitas, promosi tersebut biasanya dengan mengikuti pameran atau bazar yang diselenggarakan oleh Disperindag Kabupaten Lamongan.

d. Pemasaran langsung: Pemilik usaha kerajinan tenun ikat ini juga melakukan promosi dengan pemasaran secara langsung (Direct Marekting). Promosi tersebut dilakukan melalui media sosial seperti: Email, Instagram, Facebook, dan WhatsApp. 


\section{Tempat}

a. Distribusi secara langsung: Penyaluran produk tenun ikat secara langsung dapat dilakukan dengan cara konsumen langsung datang ke toko yang ada di Desa Parengan. Selain itu, penyaluran produk secara langsung juga bisa dilakukan ketika konsumen membeli produk secara online, dengan cara mengirimkan produk kerajinan tenun ikat secara langsung ke tempat konsumen tersebut melalui jasa pengiriman barang.

b. Distribusi secara tidak langsung: Selain pendistribusian secara langsung pemilik usaha kerajinan tenun ikat ini juga melakukan distribusi produknya secara tidak langsung yaitu melalui beberapa agen di luar kota, dengan adanya agen-agen tersebut sangat membantu pengusaha dalam memasarkan produk tenun ikat.

\section{Pembahasan}

Berdasarkan hasil penelitian yang telah dilakukan dapat diketahui bahwa pemilik usaha kerajinan tenun ikat pada CV. Silvi MN Paradila di Desa Parengan Kecamatan Maduran Kabupaten Lamongan telah menggunakan strategi pemasaran dalam menjalankan usahanya. Adapun strategi pemasaran yang diterapkan dalam mengembangkan usahanya adalah strategi bauran pemasaran. Strategi bauran pemasaran yang diterapkan memiliki beberapa elemen antara lain; produk, harga, promosi, dan tempat. Hal ini dilakukan oleh pemilik usaha kerajinan tenun ikat dengan tujuan untuk menarik minat konsumen agar membeli produk tenun ikat yang dihasilkan.

Pemilik usaha kerajinan tenun ikat di Desa Parengan dalam memproduksi tenun ikat tetap menjaga kualitas produknya dengan memilih bahan-bahan yang memiliki kualitas yang baik seperti benang dan bahan tambahan lainya. Selain itu, produk tenun ikat juga memiliki berbagai macam motif, dengan adanya berbagai macam motif tersebut maka konsumen dapat membeli produk tenun ikat sesuai dengan kebutuhan dan keinginannya. Setiap motif yang diciptakan memiliki makna tersendiri salah satu contoh makna motif yang sering diminati oleh konsumen yaitu gunungan. Motif gunungan ini sangat diminati oleh konsumen, ada beberapa alasan kenapa motif gunungan ini sangat diminati oleh konsumen. karena motif gunungan ini sudah ada sejak dulu motif ini sudah turun temurun. Sehingga banyak masyarakat yang hanya mengetahui motif gunungan. Makna dari motif gunungan sendiri yaitu merupakan salah satu lambang bahwa Lamongan memiliki banyak bukit. Sehingga motif yang banyak di produksi yaitu motif gunugan. Hal tersebut sesuai yang diungkapkan pemilik usaha kerajinan tenun ikat Bapak Miftahul Khoiri, beliau mengatakan:

"Saat ini motif yang banyak kami produksi yaitu motif gunungan mbak, karena

konsumen lebih menyukai dan banyak yang minat pada motif tersebut" (MK, $\left.55^{\text {th }}\right)$.

Selain kualitas produk yang digunakan dalam proses pembuatan tenun ikat dan juga berbagai macam motif yang tersedia, pemilik usaha kerajinan tenun ikat juga menyediakan beberapa kemasan untuk produk tenun. Kemasan yang berbentuk plastik dan kemasan kotak. Kemasan plastik digunakan untuk produk kain tenun ikat, sedangkan kemasan yang berbentuk kotak hanya digunakan untuk pembungkus sarung tenun ikat. Karena banyak konsumen yang membeli produk kain tenun ikat dibandingkan dengan sarung tenun ikat, sehingga kemasan yang banyak digunakan yaitu kemasan plastik. 
Strategi bauran pemasaran ditinjau dari segi harga juga berperan penting dalam bauran pemasaran. Pemilik usaha kerajinan tenun ikat menetapkan harga berdasarkan total keseluruhan biaya seperti biaya produksi, biaya tenaga kerja produksi, dan biaya pemasaran + keuntungan yang sudah ditentukan. Sehingga dari penentuan harga jual suatu produk tenun ikat tersebut dapat menetapkan harga produk menjadi tiga tingkatan, yaitu; rendah, sedang, dan tinggi. Seperti pendapat yang diungkapkan oleh Swastha dan Irawan (2000:80) bahwa perusahaan dapat menggunakan dua variabel marketing mix yaitu kualitas produk dan harga, menjadi beberapa tingkatan yakni: kualitas produk dengan harga tinggi, kualitas produk dengan harga sedang, dan kualitas produk dengan harga rendah. Produk yang sering diminati oleh konsumen yaitu, produk dengan harga yang rendah dan sedang. Selain itu, pemilik usaha kerajinan tenun ikat juga menetapkan harga berdasarkan permintaan konsumen, jika konsumen melakukan pembelian dalam jumlah yang banyak, maka pemilik usaha kerajinan dapat menyediakan permintaan produk sesuai dengan keinginan konsumen. Sehingga pemilik dapat menyesuaikan harga berdasarkan kualitas produk yang sesuai dengan harga yang diminta konsumen dalam pembelian produk tenun ikat.

Promosi ditujukan untuk mempengaruhi konsumen agar mengenal produk yang ditawarkan oleh perusahaan dan konsumen tertarik dalam membeli produk tersebut. Hal ini pemilik usaha kerajinan tenun ikat mempromosikan produk tenun ikat tersebut melalui pengiklanan seperti di koran, kartu nama, dan televisi. Selain itu, pemilik usaha kerajinan tenun ikat juga mempromosikan produk tenun ikat tersebut melalui publisitas, hal itu terjadi dalam pameran atau bazar yang diselenggarakan oleh Dinas Perindustrian dan Perdagangan (Disperindag) Kabupaten Lamongan, Koperasi Lamongan, BC Lamongan dan lain sebagainya. Rangkaian acara baik bazar atau pameran merupakan salah satu promosi yang dilakukan untuk memperkenalkan sekaligus menarik minat konsumen untuk membeli produk kerajinan tenun ikat asli Lamongan.

Pemilik usaha kerajinan tenun ikat di Desa Parengan juga mempromosikan produknya melalui komunikasi yang baik dan lancar melalui penjualan tatap muka (Personal Selling) yaitu melalui mulut ke mulut sehingga produk kerajinan tenun ikat cepat terdengar ditelinga para konsumen, sehingga konsumen dapat terus melakukan hal yang sama yaitu memberikan informasi tentang kerajinan tenun ikat dari mulut ke mulut. Selain itu, pemilik usaha kerajinan tenun ikat juga mempromosikan produknya secara langsung (Direct Marketing). Promosi tersebut dilakukan melalui media sosial seperti: E-mail, Instagram, Facebook, dan WhatsApp. Beberapa promosi yang dilakukan oleh pemilik usaha kerajinan tenun ikat dengan tujuan untuk memperkenalkan, menginformasikan, dan menarik konsumen untuk membeli produk tenun ikat, dari beberapa promosi tersebut kini direct marketing menjadi pasar sasaran untuk konsumen karena media elektronik yang semakin diminati, karena tersedianya berbagai macam media sosial yang dapat digunakan untuk mempromosikan produk. Seperti yang diungkapkan oleh Susatyo (2014: 57) Komunikasi langsung dengan pelanggan yang diincar secara khusus untuk memperoleh tanggapan langsung, dengan demikian maka promosi merupakan kegiatan perusahaan yang dilakukan dalam rangka memperkenalkan produk kepada konsumen sehingga dengan kegiatan tersebut konsumen tertarik untuk melakukan pembelian. Yang dimaksud dengan komunikasi secara langsung yaitu, konsumen bisa secara langsung mendapatkan respon dari produsen walaupun posisi produsen dan konsumen begitu jauh. 
Strategi bauran pemasaran yang berperan penting dalam suatu usaha salah satunya adalah distribusi. Distribusi yaitu saluran pemasaran yang dilakukan oleh pemilik usaha kerajinan tenun ikat di Desa Parengan guna produknya dapat tersalurkan kepada konsumen dengan tepat sasaran. Distribusi yang dilakukan pemilik usaha kerajinan tenun ikat di Desa Parengan melalui penyaluran secara langsung yaitu konsumen bisa langsung datang ke toko sekaligus tempat produksi yang ada di Desa Parengan Kecamatan Maduran Kabupaten Lamongan. Selain itu, penyaluran secara langsung juga dapat dilakukan dengan konsumen membeli produk secara online maka produk tenun ikat tersebut akan secara langsung dikirim melalui jasa pengiriman barang seperti; kantor pos, JNE, dan lainya. Distribusi secara langsung bermanfaat bagi pemilik usaha kerajinan tenun ikat agar produk dapat tersalurkan dengan terarah pada konsumen yang potensial. Fakta tersebut sesuai dengan pendapat yang diungkapkan oleh Kotler dan Keller (2009:241) pemasaran langsung dapat menjangkau calon pelanggan pada saat yang tepat dan dibaca oleh pelanggan yang lebih memiliki prospek.

Selain distribusi secara langsung pemilik usaha kerajinan tenun ikat ini juga melakukan pendistribusian secara tidak langsung yaitu dengan melakukan kerjasama kebeberapa agen yang ada di luar kota seperti Jakarta, Bandung, Sidoarjo, Surabaya, Kalimantan Timur. Distribusi tidak langsung ini sangat membantu pemilik usaha kerajinan tenun ikat dalam memasarkan produknya, dengan adanya beberapa agen di luar kota maka produk tenun ikat dapat dikenal oleh konsumen luar daerah Kabupaten Lamongan. Seperti yang diungkapkan oleh Maulana (1999:329) bahwa perantara (saluran distribusi tidak langsung) seringkali dapat membantu produsen memenuhi kebutuhan pelanggan secara lebih baik.

Berdasarkan data yang diperoleh dari subjek penelitian yaitu pemilik usaha kerajinan tenun ikat di Desa Parengan Kecamatan Maduran Kabupaten Lamongan menunjukkan bahwa pemilik usaha memiliki sistem pendistribusian secara langsung dan secara tidak langsung agar tepat sasaran dan lebih optimal ketangan konsumen. Penyaluran produk kerajinan tenun ikat yang diterapkan oleh pemilik usaha kerajinan tenun ikat membuat usaha kerajinan tenun ikat ini bisa bertahan sampai saat ini. Selain itu, usaha tersebut menjadi salah satu pusat sentra kerajinan tenun ikat di Desa Parengan Kecamatan Maduran Kabupaten Lamongan.

\section{KESIMPULAN DAN SARAN \\ Kesimpulan}

Berdasarkan hasil penelitian dan pembahasan yang sudah dilakukan oleh peneliti kepada informan utama mengenai strategi bauran pemasaran kerajinan tenun ikat pada CV. Silvi MN Paradila di Desa Parengan Kecamatan Maduran Kabupaten Lamongan, maka dapat disimpulkan bahwa pemilik usaha kerajinan tenun ikat menerapkan strategi bauran pemasaran dalam memasarkan produknya, yaitu melalui strategi produk, strategi harga, strategi promosi dan strategi tempat.

Strategi produk yang dilakukan oleh pemilik usaha kerajinan tenun ikat CV. Silvi MN Paradila adalah menjaga kualitas produk yaitu dengan memilih bahan-bahan yang memiliki kualitas bagus. Selain itu, menyediakan berbagai macam motif dan menjadikan icon Kabupaten Lamongan motif ikan bandeng dan lele untuk menarik minat konsumen serta menyediakan beberapa kemasan produk. Strategi harga yang dilakukan yaitu, dengan menetapkan harga jual 
dari biaya produksi dan profit margin. Selain itu, menetapkan harga berdasarkan 3 tingkatan yaitu, tingkatan rendah, sedang, dan tinggi.

Selain itu, strategi promosi yang dilakukan adalah dengan penjualan perorangan (personal selling) yaitu, bertatap muka secara langsung dengan konsumen, pengiklanan yaitu, melalui kartu nama, dan media sosial seperti; Email, WhatsApp, Instagram, Facebook. Publisitas yaitu, melalui bazar atau pameran yang diselenggarakan oleh Disperindag Kabupaten Lamongan. Saluran distribusi yang digunakan pemilik usaha kerajinan tenun ikat yaitu, saluran distribusi langsung yang mana konsumen bisa langsung datang ke toko yang ada di Desa Parengan, saluran distribusi tidak langsung konsumen bisa membeli secara online atau melalui agen-agen yang tersedia diberbagai kota di Indonesia.

\section{Saran}

Berdasarkan kesimpulan dari penelitian ini maka dapat diberikan saran kepada pemilik usaha kerajinan tenun ikat CV. Silvi MN Paradila di Desa Parengan Kecamatan Maduran Kabupaten Lamongan yaitu tetap mempertahankan dan terus meningkatkan produk kerajinan tenun ikat Kabupaten Lamongan.

\section{DAFTAR BACAAN}

Herlambang, Susatyo. 2014. Basic Marketing (Dasar-Dasar Pemasaran) Cara Mudah Memahami Ilmu Pemasaran. Yogyakarta: KDT.

Irawan. dan Swastha, Basu. 2000. Manajemen Pemasaran Modern. Yogyakarta: Liberty.

Kotler, P. dan Keller, K. L. 2009. Manajemen Pemasaran. Edisi 13. Jilid 2. Jakarta: Erlangga.

Philip, Kotler dan Gary, Armstrong. 2008. Prinsip-prinsip pemasaran Jilid 1 edisi 12. Jakarta: Penerbit Erlangga.

Rahmady, Radiany dan Sularso, Andi. 2007. Kosentrasi Pemasaran. Surabaya: Badan Penerbit Mahardhika.

Subagyo Ahmad. 2010. Marketing in Business. Jakarta: Mitra Wacana Media.

Tjiptono, Fandy. 2008. Pemasaran Strategik. Yogyakarta: Andi Offset. 